\title{
A INJUSTIÇA SOCIAL REFLETIDA NO ACESSO À JUSTIÇA NO SISTEMA PENAL BRASILEIRO ATUAL - UM ESTUDO DA REPROVAÇÃO SÓCIO- JURÍDICA AOS POBRES QUE COMETEM DELITOS BAGATELARES
}

\author{
SOCIAL INEQUITY REFLECTED IN THE ACCESS TO JUSTICE IN THE BRAZILIAN PREVAILING \\ CRIMINAL SYSTEM - AN ANALYSIS OF THE SOCIAL-JURIDICAL REPRIMAND TO POOR PEOPLE \\ IN MINOR CRIMES
}

Bianca Leão Bertin*

\begin{abstract}
Resumo:
O presente estudo tem o intuito de analisar a reprovação jurídica e social que recai àqueles menos favorecidos financeiramente no que se refere ao cometimento de delitos de menor importância no Brasil. Esse estudo reflete sobre o fato de o Sistema Penal brasileiro prever uma punição desproporcional em relação a condutas delituosas consideradas insignificantes socialmente. Objetivo é mostrar que o Direito Penal brasileiro, tal como se apresenta, seleciona alguns, vulneráveis ao sistema, e, assim, expõe seu poder atemorizante e impositivo, demonstrando desse modo um caráter elitista e dominador.
\end{abstract}

Palavras-Chave: Acesso à Justiça. Injustiça Social. Crimes Bagatelares. Princípio da Insignificância.

\begin{abstract}
:
The purpose of this work is to analyze the social and legal reprimand that befalls those lest economically favored concerning minor crimes in Brazil. This work reflects about the disproportionate punishment envisaged in the Brazilian Legal System for illegal activities considered socially insignificant. The objective is to demonstrate that the Brazilian Criminal Code, as is it now, select a few, vulnerable to the system, and, by doing that, expose his fearful and overbearing power, revealing this way an elitist and dominant feature.
\end{abstract}

Keywords: Access to Justice. Social Inequity. Minor Crimes. Principle of Insignificance.

Introdução

O trabalho a seguir é dividido em três partes.

A primeira parte, intitulada "Crime e Castigo", ${ }^{1}$ é um estudo jurídico a respeito da reprovação em relação aos crimes bagatelares, isto é, reprovação na esfera penal a respeito de furtos que por serem considerados de pequena monta são denominados

\footnotetext{
* Aluna do Curso de Graduação da Faculdade de Direito da Universidade de São Paulo. E-mail: bianca.bertin@ ig.com.br.

1 Esse título é uma clara intertextualidade com a obra homônima de Fiódor Mikhailovitch Dostoiévski (18211881). Nessa obra é narrada a história de um jovem, que em meio à pobreza da Rússia Czarina, comete um crime e é duramente castigado por suas próprias crises de consciência.
} 
insignificantes perante à sociedade. Tais ações são consideradas incapazes de lesionar a sociedade a ponto de merecerem uma repressão na esfera penal.

Primeiramente, fazem-se considerações a respeito do Direito Penal Mínimo, ou seja, defende-se que ao direito penal é lícito o envolvimento em matérias densas, capazes de provocar forte lesão à vida do indivíduo; entretanto, quanto a matérias de pouca relevância à sociedade e à vida das pessoas, como por exemplo, no caso de uma pessoa pobre que furta uma lata de refrigerante em um supermercado de uma grande empresa, defende-se que tal ação em hipótese alguma deve ter relevância jurídica de modo a mover as engrenagens da esfera penal. Embora tal raciocínio pareça elementar, há formas de pensar que pregam justamente o contrário, por exemplo, políticas denominadas "Tolerância Zero", "Movimentos Lei e Ordem" ou "Direito Penal do Inimigo", para as quais deve ser estabelecida uma forte intervenção penal na vida dos indivíduos, deve haver uma expansão do direito penal como forma de disciplinar e controlar os cidadãos; para tais visões, até mesmo condutas de menor importância devem estar inseridas no ramo penal do direito, pois para essas correntes uma infração pequena, caso seja tolerada, poderia dar ensejo a que tantas outras graves fossem cometidas. Esta primeira parte do trabalho, pois, tem por alvo descaracterizar tais pensamentos e, através da exposição de argumentos jurídicos, pretende demonstrar que em relação a condutas de menor ofensividade cabe não o ato de criminalizar, mas a descriminalização com base na proporcionalidade, na necessidade, no raciocínio da intervenção penal mínima, na subsidiariedade e fragmentaridade do direito penal.

Faz-se, também, o estudo do delito bagatelar no âmbito penal, ou seja, analisa-se o bem jurídico envolvido e a tipicidade de tais atos. Finalmente, discorre-se a respeito da aplicação do Princípio da Insignificância em relação a esses pequenos furtos, e a aceitação desse princípio por parte da sociedade.

Tendo em mente que muitos dos furtos de pequena importância são cometidos pelos excluídos sociais, "os vulneráveis" nas palavras de Zaffaroni, tal estudo discorre a respeito da situação de desamparo dos pobres os quais cometem os delitos de bagatela e são selecionados pelo sistema penal, muitas vezes, permanecendo aprisionados durante meses. Nessa etapa do trabalho, há ênfase no modo como o pobre é visto e tratado pela sociedade, ou seja, há a exposição da forma preconceituosa com que os pobres são vistos e selecionados pelo sistema penal. Essa segunda parte do estudo é denominada "Os Miseráveis". ${ }^{2}$ Nela, sob uma visão criminológica e sociológica, faz-se uma análise a respeito da inquietante indagação "Por que os mais pobres são punidos com maior rigor?”.

\footnotetext{
Clara intertextualidade com a obra homônima de Victor Marie Hugo (1802-1885). Esse romance faz uma narrativa da saga de Jean Valjean que, em meio a uma série de acontecimentos, é condenado e perseguido por se apoderar de um pão, o qual serviria para alimentar sete crianças famintas. Interessante o caráter social e político que a obra apresenta, ela, de fato, mostra não só a miséria física exposta em uma França carcomida pela pobreza; mas, também, misérias arraigadas nos espíritos humanos.
} 
Como se sabe, não é recente a ligação existente entre direito penal e poder de dominação das classes mais favorecidas. Para alguns pensadores, como Nilo Batista, essa relação gira em torno de se firmar um exército de reserva de mão-de-obra, vez que, para ele, a punição se refere sobretudo, e desde sempre, ao mercado econômico, tal como o exposto na obra "Punidos e Mal Pagos". Para se chegar a uma conclusão dessa monta foi essencial a utilização, também, de pensamentos de autores como Michel Foucault e Alessandro Baratta. O objetivo é expor que o direito penal é um instrumento de poder e controle que uma classe dominante manipula a fim de garantir seus interesses. $\mathrm{O}$ intuito dessa análise no trabalho é estabelecer que o sistema penal seleciona sobretudo os excluídos e, através deles, aflora seu poder autoritário e intimidador, "aterrorizante", ${ }^{3}$ digno de ser temido e respeitado.

Entretanto, conforme estabelece Michel Foucault, de qualquer forma de poder advém formas de resistência, ${ }^{4}$ a terceira parte, intitulada "Um Admirável Mundo Novo", 5 além de se propor a apresentar uma visão aguçada do direito penal aplicado aos pobres, por meios de críticas, trata, também, de alguns avanços do direito penal brasileiro.

Com efeito, observa-se algumas melhorias no âmbito penal brasileiro como a previsão constitucional de princípios e garantias, os aumentos de atuação das defensorias públicas, o advento dos juizados especiais, etc; contudo, não se pode deixar de mencionar uma infinidade de problemas no âmbito penal como se verifica nas condições precárias em que se encontram as instituições punitivas brasileiras, a desigualdade social ao que se refere ao acesso à justiça, a resistência por parte de muitos em aceitar formas racionais de descriminalização de condutas irrelevantes para a sociedade, a resistência à aplicação do Princípio da Insignificância, etc.

Verifica-se, pois, que muitas questões continuam sobressaltando todos aqueles que se interessam não só por questões de direito, mas por questões de justiça.

O estudo, em suma, tem por objetivo maior reafirmar, em outras palavras, o que deliberou muitos pensadores: muitas vezes o direito penal usa de uma violência

FOUCAULT, Michel. Vigiar e punir. Tradução de Raquel Ramalhete. 35. ed. Rio de Janeiro: Editora Vozes, 2008. p. 42.

4 Tal pensamento foi tragado de uma série de artigos expostos em: FOUCAULT, Michel. Microfisica do poder. Tradução e organização de Roberto Machado. 26. ed. Rio de Janeiro: Editora Graal, 1979.

5 Intertextualidade com a obra Brave New World de Aldous Leonard Huxley (1894-1963). Essa obra é uma ficção futurística que tem por tema uma sociedade alienada, um Governo totalitário, absoluto e um controle social baseado em divisões rígidas de classe utilizando a ciência para esse fim, pois, de acordo com a alimentação que era fornecida para os embriões, o indivíduo se posicionaria, no futuro, na obra, em uma determinada classe social. É de se notar que as traduções para o português adotam o título "Admirável Mundo Novo", diferentemente, se adota nesse estudo o artigo indefinido "um" na frente do título. Tal procedimento tem o intuito de criar um efeito que sugere que o futuro da sociedade atual não precisa ser como o da obra, sem perspectivas, fechado, com o Estado ditando normas e as pessoas as acolhendo automaticamente. Ao invés, deseja-se que o futuro seja o contrário. 
desproporcional e irracional para com questões de fácil solução prática. Os prejudicados por isso, naturalmente, são os mais fracos, os vulneráveis, os miseráveis. No entanto, como se pode aferir do pensamento de Alessandro Baratta, ${ }^{6}$ o ser humano é tão surpreendente que seria capaz de altivamente se sobrepor, apesar do direito penal.

PARTE I: Crime e Castigo

"não há castigo suficientemente horrivel para impedir que roube quem não tem outra maneira de prover à sua carência mais extrema: a fome"

(Thomas More, “A Utopia”)

1. Considerações sobre a intervenção mínima do Direito Penal

É notório que a proteção exercida pela esfera penal em um Estado Democrático de Direito deve estar vinculada à Carta Magna de tal país. A partir de tal afirmação entende-se que a liberdade de que goza o Direito Penal é limitada; ${ }^{8}$ o Direito Penal deve, também, obedecer à proporcionalidade quanto ao tratamento em relação aos bens envolvidos nas questões (deve-se sopesar, por exemplo, a proteção ao bem lesado e a liberdade delimitada pelo Direito Penal).

Ademais, é importante que se lembre que a Constituição brasileira de 1988 adotou um viés de caráter social, uma Constituição protetora ao que se refere às liberdades individuais. A Constituição Federal de 1988 caracteriza-se, portanto, a fonte dos bens penalmente tutelados e, dessa forma, preza cumprir seu "iluminado dever": preservar a dignidade da pessoa humana. ${ }^{9}$

Há quem entenda que uma conduta pode ser inserida no rol do Direito Penal se não fere o disposto na Constituição Federal. Esse entendimento é denominado de limite negativo ao Direito Penal. Outros entendem que, para que uma conduta seja declarada

6 Pensamento desenvolvido por meio da leitura da obra: BARATTA, Alessandro. Criminologia crítica e crítica do direito penal. Tradução de Juarez Cirino dos Santos. 3. ed. Rio de Janeiro: Editora Revan, 2002.

7 Esse trecho da obra de Thomas More (1477-1535) não deve ser aplicado ao que se refere aos crimes bagatelares (um dos objetos de estudo do presente trabalho), pois o furtar para se alimentar não é entendido como crime bagatelar. Segundo Janaina Conceição Paschoal "quando alguém subtrai coisa alheia móvel para saciar fome que coloca em risco sua própria sobrevivência (...) não se pode falar em conduta típica" (PASCHOAL, Janaina Conceição. Direito penal: parte geral. 1. ed. São Paulo: Editora Manole, 2003. p. 44).

8 PASCHOAL, Janaina Conceição. Constituição, criminalização e direito penal mínimo. 1. ed. São Paulo: Editora Revista dos Tribunais, 2003. p. 128 e ss.

9 Id. Ibid., p. 129 e ss. 
como criminosa, há de se verificar lesão a bens previamente expressos e determinados na Constituição Federal. Tal entendimento é conhecido como limite positivo ao Direito Penal. ${ }^{10}$ Ainda, há outros que consideram que a proteção penal deve estar diretamente vinculada aos direitos fundamentais. Disso decorre que o Direito Penal deve ser utilizado como último recurso, "ultima ratio", ou seja, somente em ocasiões em que esse tipo de intervenção é realmente necessário; o Estado, portanto, deve se valer do Direito Penal nos casos mais graves. ${ }^{11}$

Para Zaffaroni, o princípio da intervenção mínima é o mesmo que interposição de limites à punição; para o autor, está ligado à redução da violência das formas de punição e ao acolhimento dos Direitos Humanos. ${ }^{12}$

Partindo-se do raciocínio de que o Direito Penal não deve ser entendido como o meio supremo de se resolver problemas, mas como um meio como tantos outros, ou melhor, um meio mais brutalizado do que os outros, desenvolveram-se alguns princípios em prol da intervenção mínima do Direito Penal:

Subsidiariedade, segundo essa idéia, o Estado deve priorizar a resolução dos problemas através da utilização de outros ramos do direito (como a utilização do direito civil, ou do direito administrativo, etc.), ou até mesmo de outros meios (como a utilização de acordos, de negociações, de mediações, etc.). ${ }^{13}$

Fragmentaridade, de acordo com essa idéia, mesmo que um bem esteja inserido no rol de proteção da esfera penal, e haja todas as circunstâncias para a aplicação da lei penal, há determinadas situações em que essa característica protecionista deve ser ignorada. ${ }^{14}$ Por exemplo, Alberto Silva Franco proferiu votos que expunham a atipicidade de condutas danosas que não possuíam caráter relevante para que houvesse uma aplicação de pena. ${ }^{15}$ Também, muitos juízes se enveredaram por essa linha de raciocínio em nome de uma boa política criminal.

Segundo o Princípio da lesividade ou ofensividade, mesmo que haja proteção penal a um bem, e mesmo que um ato delituoso ocorra em relação a esse bem, se tal ato não gerou lesão ou perigo, ele deve ser ignorado penalmente. ${ }^{16} \mathrm{O}$ princípio da lesividade

10 PASCHOAL, Janaina Conceição. Constituição, criminalização e direito penal mínimo. 1. ed. São Paulo: Editora Revista dos Tribunais, 2003. p. 49 e ss.

11 VICO MAÑAS, Carlos. Tipicidade e princípio da insignificância. 1993. Tese. (Mestrado) - Faculdade de Direito, Universidade de São Paulo. São Paulo. p. 55 e ss.

12 ZAFFARONI, Eugenio Raúl; PIERANGELI, José Henrique. Manual de direito penal brasileiro: parte geral". 7. ed. São Paulo: Editora Revista dos Tribunais, 2008. v. 1, p. 74-77.

13 PASCHOAL, Janaina Conceição. Direito penal... cit., p.16-17.

14 Id. Ibid., p.16-17.

15 SUANNES, Adauto. Bagatelas. Boletim IBCCRIM, São Paulo, n. 200, jul. 2009. p.15.

16 PASCHOAL, Janaina Conceição. Direito penal... cit., p. 16-17. 
é bastante condizente com o princípio da insignificância o qual defende a atipicidade material em relação a pequenos delitos incapazes de lesionar a sociedade.

O raciocínio da intervenção penal mínima, portanto, com o resguardo da proporcionalidade, subsidiariedade, fragmentaridade e análise da ofensividade, propõe uma visão mais libertária, ou seja, propõe a descriminalização de certas condutas, como em relação aos delitos bagatelares. A visão do direto penal mínimo argumenta que tais delitos não afrontam bens jurídicos dignos de serem tutelados pelo ramo penal do direito e, materialmente, essas condutas são atípicas. ${ }^{17}$

Há correntes que argumentam o oposto, ou seja, frisam que as condutas de pequena monta devem ser punidas com rigor para que haja o temor do cometimento de condutas mais graves. Essas correntes pregam, pois, uma maior intervenção do Direito Penal nas vidas das pessoas. Exemplos desse entendimento são as políticas "Tolerância Zero" e "Movimentos Lei e Ordem". O disposto no pensamento do "Direito Penal do Inimigo", desenvolvido por Günther Jakobs, também pode ser tido como um entendimento de maximização do Direito Penal, uma vez que argumenta que alguns não devem ser tratados como pessoas pelo fato de terem cometido delitos. Segundo essa forma de pensar, o Direito Penal deve visar à proteção de bens sociais através da eliminação de inimigos perigosos ao sistema. ${ }^{18}$ Inimigos devem ser tratados como tais, muitas vezes, sendo eliminados da esfera de convívio por meio da pena de morte.

No entanto, é definitivamente inconcebível a aceitação de tal modo autoritário de pensar. Argumentos dessa sorte foram combatidos séculos atrás com as idéias de proporcionalidade, respeito e igualdade defendidas por Cesare Beccaria. Na obra "Dos Delitos e das Penas", Beccaria afirma que o fato de os indivíduos concederem ao Estado parte de sua liberdade com o intuito de se estabelecer um bem social para proteção geral, não significa que estejam dispondo de suas vidas. A conclusão é simples: a pena de morte não é apoiada pelo Direito, as leis devem ter a função de proteção; afinal, "quem poderia conceder a homens o direito de degolar seus iguais?"19

2. Análise jurídica em relação aos crimes bagatelares no Direito Penal brasileiro

\footnotetext{
17 ZAFFARONI, Eugenio Raúl; PIERANGELI, José Henrique. Manual de direito penal brasileiro: parte geral. 7. ed. São Paulo: Editora Revista dos Tribunais, 2008. p. 383 e ss.

18 SILVEIRA, Renato de Mello Jorge. Crimes sexuais: bases críticas para a reforma do direito penal sexual. 1. ed. São Paulo: Editora Quartier Latin, 2008. p. 187-189.

19 BECCARIA, Cesare. Dos delitos e das penas. Tradução de Torrieri Guimarães. São Paulo: Editora Martin Claret, 2006. p. 51 e ss.
} 


\subsection{Considerações a respeito do bem jurídico em relação a crimes de bagatela}

Hoje, muitos concordam que o Direito Penal possui como fim a proteção de bens jurídicos caros ao homem como a vida, a liberdade, a integridade física, o patrimônio, a administração pública, etc. ${ }^{20}$ Muitos autores ensinam que a escolha de bens jurídicos de direito devem atender ao que a sociedade encara como lesivo ou não a ela, ou seja, há a dependência de um interesse social ${ }^{21}$ quanto a essa escolha: Antônio Camargo Luis Chaves indica que o bem jurídico é um reflexo dos valores sociais, ${ }^{22}$ Juarez Tavarez atenta para a importância de se verificar concepções jurídicas de acordo com uma óptica social, ${ }^{23}$ para Miguel Reale o direito se liga necessariamente a experiência social. ${ }^{24}$

Ao contrário das admoestações de Günther Jakobs, o qual considera que a função essencial do Direito Penal é o resguardo da norma, sem que haja a consideração de qualquer fator fora da esfera normativa ${ }^{25}$ - admoestação essa que possui forte caráter totalitário justificado juridicamente, de acordo com esse racicíonio -, Zaffaroni atenta para o fato de o direito adquirir um caráter ético na medida em que está comprometido com os valores constituídos pela sociedade. Para Zaffaroni o bem jurídico penalmente tutelado adquire função garantidora, pois é através dele que a lei penal adquire sentido perante a sociedade. $^{26}$

Tendo-se, pois, os interesses sociais como pilar de sustentação ao que se refere a bens jurídicos penais, constata-se que a preocupação do Direito Penal em se apontar determinado ato como passível de ser punido com rigor (penalmente) deve levar em conta a lesividade de tal ato. Para Janaína Conceição Paschoal, "apenas as efetivas lesões, ou exposições concretas a perigo" deveriam justificar o uso do Direito Penal. ${ }^{27}$ Zaffaroni considera que o Direito Penal deve-se voltar apenas a atos que atinjam "de forma intolerável" o bem jurídico tutelado. ${ }^{28}$

Crimes bagatelares, ou de pequena importância, jamais poderiam ser tidos como causadores de "efetivas lesões" ou "expositores de perigo". Se fossem considerados

\footnotetext{
ZAFFARONI, Eugenio Raúl; PIERANGELI, José Henrique. Manual de direito penal brasileiro... cit., p. 403. PASCHOAL, Janaina Conceição. Constituição, criminalização e direito penal mínimo... cit., p. 46-47.

22 CAMARGO, Antonio Luis Chaves. Motivo, vontade, intenção, dolo. 1986. Tese (Livre Docência) - Faculdade de Direito, Universidade de São Paulo. São Paulo. p. 7-14.

23 TAVARES, Juarez. Critérios de seleção de crimes e cominação de penas. Revista Brasileira de Ciências Criminais, São Paulo, n. esp., dez. 1992. p. 78-81.

24 REALE, Miguel. Teoria tridimensional do direito. 3. ed. São Paulo: Editora Saraiva, 1980. p. 79-80.

25 JAKOBS, Günther. Sociedade, norma e pessoa. Tradução de Maurício Antonio Ribeiro Lopes. 1. ed. São Paulo: Ed. Manole, 2003. p. 10-20.

26 ZAFFARONI, Eugenio Raúl; PIERANGELI, José Henrique. Manual... cit., p. 89-91.

27 PASCHOAL, Janaina Conceição. Constituição, criminalização e direito penal mínimo. 1. ed. São Paulo: Editora Revista dos Tribunais, 2003. p. 48.

28 ZAFFARONI, Eugenio Raúl; PIERANGELI, José Henrique. Manual... cit. p. 90.
} 
como tais, obviamente se recairia em um paradoxo e em uma desproporção. Tais delitos devem ser interpretados segundo uma perspectiva material (socialmente valorada), de modo que se obtenha uma mínima intervenção do Direito Penal, resguardando assim a proporcionalidade, necessidade, subsidiariedade e fragmentaridade do Direito Penal. Conclui-se disso que não é desejável que o Direito Penal atue além da proteção necessária ao bem jurídico; o Direito Penal não deve se ocupar em estabelecer penalidades em relação a delitos bagatelares uma vez que eles são insignificantes perante a sociedade.

$\mathrm{O}$ direito deve priorizar o bem jurídico mais relevante; essa característica funciona justamente como um instrumento limitador dos poderes punitivos do Estado. ${ }^{29}$ É precisamente pelo fato da existência desse limite que se pode verificar a vivência em um Estado Democrático de Direito.

\subsection{Considerações a respeito da tipicidade em relação a delitos bagatelares}

O tipo penal se faz necessário para que se descreva uma conduta como sendo delituosa. Segundo Zaffaroni, o tipo tem por função individualizar atos humanos penalmente relevantes. ${ }^{30}$

Verifica-se na tipicidade uma das aplicações mais notáveis do princípio da legalidade, segundo o qual se faz necessário que haja uma conduta previamente definida no ordenamento para que existam conseqüências jurídicas.

Inicialmente, há a concepção de tipo proposto por Ernest Von Beling. Sob a óptica desse pensador o tipo é entendido como representação legal da conduta e, priorizandose a objetividade nos âmbitos jurídicos, o entendimento da conduta típica é desprovido de todo e qualquer conteúdo subjetivo, ou seja, na medida em que um ato é cometido ele tem a sua correspondência na esfera normativa, mas quanto às circunstâncias que desencadearam tal ato, elas são ignoradas. Para Beling, a conduta deveria se ajustar formalmente; se existissem excessos ou escassezes nela, a conduta seria qualificada como atípica. ${ }^{31}$

Já os finalistas, ao que se refere à tipicidade, passam a levar em conta conteúdos subjetivos caracterizados pela intenção do agente. Assim, nessa visão, o dolo e a culpa são utilizados para se ordenar determinadas condutas. Busca-se, dessa forma, um fim nas ações; os resultados devem ser buscados nessa perspectiva.

Contudo, tal entendimento não contemplou a óptica valorativa-social. Hans Welzel aperfeiçoou a idéia de tipo, desenvolveu três caracteres específicos (tipicidade, antijuricidade e culpabilidade), os quais são utilizados largamente nos dias de hoje.

\footnotetext{
PASCHOAL, Janaina Conceição. Constituição... cit., p. 48.

ZAFFARONI, Eugenio Raúl; PIERANGELI, José Henrique. Manual... cit., p.384. ; PIERANGELI, José Henrique. Manual de direito penal brasileiro: parte geral. 7. ed. São Paulo:

Editora Revista dos Tribunais, 2008. p. 389-390.
} 
Desenvolveu a teoria da adequação social, em que leva em conta não só a finalidade do ato, mas também a adequação do ato aos valores aceitos pela sociedade. Tal teoria prega que condutas que não são mais alvos de reprovação social, ainda que formalmente típicas, devem ser excluídas do âmbito penal. ${ }^{32}$

Próximo a esse raciocínio, Clauss Roxin, por volta de 1970, defende que as condutas devem ser consideradas sob a perspectiva valorativa-social; formula, assim, o Princípio da Insignificância, que prega a atipicidade em relação a condutas que não ofendem ou lesionem de modo acentuado os bens jurídicos tutelados pela esfera penal. ${ }^{33}$ Em sua obra intitulada "Política Criminal e Sistema de Direito Penal", admoesta que o Direito Penal não deve se pautar em direitos prévios; não se pode conceber um Direito Penal fechado, pois isso geraria insegurança jurídica e injustiças. Por essa lógica, o ideal seria que o Direito Penal se mostrasse o mais lacunoso possível. O sistema deve, pois, ser aberto; isso geraria oportunidades de se verificar cada situação. É importante lembrar que no sistema penal se classificam condutas delituosas das mais variadas categorias. Uma conduta, portanto, poderia ser intitulada como criminosa, mas não precisaria receber como punição a reclusão. A justiça, nesse caso, seria o alvo a se alcançar.

Desses pensamentos, pode-se concluir, que uma conduta, ainda que classificada como formalmente típica, pode se apresentar materialmente atípica. Zaffaroni ensina que o fato de uma conduta se adequar formalmente a uma descrição típica, mas não ser lesiva ao bem jurídico não pode ser incluída no tipo. ${ }^{34}$

No Brasil, esse entendimento aflorou com a publicação da obra "O princípio da insignificância como excludente da tipicidade no Direito Penal", de Carlos Vico Mañas, em 1994; nessa obra é estabelecido que o Direito Penal não se faz necessário para resolver todos os problemas jurídicos. Nela há distinção entre atos ilícitos e atos típicos e defende-se que muitas condutas que atualmente são punidas penalmente, dentre estas os delitos bagatelares, podem ser punidas por outras esferas judiciais como civil, administrativa, etc. A obra esclarece que os delitos bagatelares não devem ser punidos com a privação do bem jurídico liberdade, pois tal punição caracterizaria não só uma afronta ao princípio da proporcionalidade ao que se refere à necessidade, mas também uma medida ineficaz de se garantir a segurança jurídica social, pois um indivíduo que pelo fato de ter cometido um delito de pequena monta, sofrer uma ação penal, e enfrentar os dissabores do sistema penitenciário brasileiro, seria gravosamente ferido em sua integridade, e talvez, estigmatizado. Talvez jamais pudesse se reinserir na vida social.

\footnotetext{
32 ZAFFARONI, Eugenio Raúl; PIERANGELI, José Henrique. Manual de direito penal brasileiro: parte geral. 7. ed. São Paulo: Editora Revista dos Tribunais, 2008. p. 391.

33 SILVEIRA, Renato de Mello Jorge. Linhas reitoras da adequação social em direito penal. 2009. Tese (Titular) - Faculdade de Direito, Universidade de São Paulo. São Paulo. p. 202 e ss.

34 ZAFFARONI, Eugenio Raúl; PIERANGELI, José Henrique. Manual... cit., p. 395-396.
} 
Embora haja resistência por parte do sistema judiciário quanto à aceitação de se considerar os crimes bagatelares como materialmente atípicos, e, sendo assim aplicar o Princípio da Insignificância, é inegável que houve um progresso em relação ao assunto. Esse modo de classificação tem sido aceito no Supremo Tribunal Federal: "verificada a objetiva insignificância jurídica do ato tido por delituoso, é de ser extinto o processo da ação penal, por atipicidade do comportamento e conseqüente inexistência de justa causa", conforme se pode verificar a partir do relatado pelo ministro Cezar Peluzo, ao que se refere ao Habeas Corpus n. 88.393. ${ }^{35}$

Tal fragmento pode ser apontado como um progresso em relação a se considerar os crimes bagatelares como atípicos materialmente, entretanto, há correntes contrárias a essa posição. Por exemplo, o pensamento de Lúcio Antônio Chamon Júnior, autor mineiro, o qual declara que mesmo se uma conduta estiver no rol da insignificância, seria impróprio considerá-la atípica, pois, segundo essa posição, isso se tornaria um afronto à propriedade e à posse. ${ }^{36}$ Reforçando essa idéia, o referido autor ainda critica o entendimento do Supremo Tribunal Federal, em relação ao Habeas Corpus n. 84.412, pelo fato de se ter qualificado a conduta da apropriação de vinte e cinco reais como atípica e por se aplicar o Princípio da Insignificância, nesse caso. O Autor afirma que mesmo que essa quantia possa ser considerada ínfima, deveria ter havido a aplicação da "pena adequada", ou seja, segundo o ordenamento brasileiro, reclusão de um a quatro anos e multa. ${ }^{37}$

\section{Princípio da Insignificância}

\subsection{Considerações a respeito do Princípio da Insignificância}

O Princípio da Insignificância está solidamente vinculado a idéia da intervenção penal mínima juntamente com o resguardo da proporcionalidade-razoabilidade ao que se refere à pena.

Dentre as vantagens em decorrência da aplicação do Princípio da Insignificância pode-se apontar maior eficiência da justiça penal, ${ }^{38}$ isto é, com o afastamento de questões de pouca relevância ao que se refere ao âmbito penal, o sistema penal pode se voltar atentamente a questões de maior importância a essa esfera, por exemplo, averiguações de crimes de homicídios, etc. Além disso, deve-se verificar que o alto custo

SUANNES, Adauto. Bagatelas. Boletim IBCCRIM, São Paulo, n. 200, jul. 2009. p.15.

SILVEIRA, Renato de Mello Jorge. Linhas reitoras da adequação social em direito penal. cit., p. 206.

Id. Ibid., p. 207-210.

38 SILVEIRA, Renato de Mello Jorge. Linhas reitoras da adequação social em direito penal. 2009. Tese (Titular) - Faculdade de Direito, Universidade de São Paulo. São Paulo. p. 205. 
social e econômico que uma pena privativa de liberdade possui só se mostra justificável se for aplicada em decorrência de uma ação digna disso. ${ }^{39}$

À aplicação do Princípio da Insignificância devem ser resguardadas, entretanto, determinadas condições: para muitos, a conduta deve recair nos delitos referentes ao patrimônio; a ação delituosa deve ser desprovida de qualquer forma de violência; e, conforme alguns entendimentos, os delitos dessa espécie cometidos na esfera administrativa estariam fora do âmbito penal, ou seja, delitos dessa sorte devem ser apurados segundo procedimento administrativo. Importante ressaltar que o furtar coisa móvel para não perecer de fome não se insere dentre os delitos bagatelares, pois esse tipo de conduta nem sequer deve ser considerada formalmente típica. ${ }^{40}$

A proporcionalidade em relação aos bens jurídicos certamente não deve ser ignorada, ou seja, o Direito Penal intervém em um bem jurídico caríssimo ao homem (estabeleceu-se que o bem jurídico liberdade tomasse essa posição visto que ele é precioso tanto para o rico quanto para o pobre; além disso, para melhor resguardo da idéia de proporcionalidade, deve-se estabelecer a individualização da pena como forma de se alcançar equilíbrio ao que se refere a "delitos-castigos" ${ }^{41}$ ), logo, para que se tenha equiparação de bens, somente se houver lesão a um bem pareado com o bem liberdade pode-se admitir o uso legítimo do Direito Penal. Também, deve ser estabelecida a proporcionalidade que uma pena deve ter em relação à gravidade da conduta criminosa. ${ }^{42}$

Tal raciocínio acertadamente deve ser utilizado ao que se refere aos crimes bagatelares, pois o bem jurídico liberdade é mais caro ao homem do que meros objetos de pequeno valor. Também, seria inconcebível a admissão de que os delitos bagatelares (furtos de objetos sem grande valor econômico) seriam graves a ponto desembocarem na privação da liberdade. ${ }^{43}$

Portanto, para haver uma intervenção do Direito Penal, a conduta deve ser tida como perigosa ou como ofensiva ao bem jurídico resguardado pelo Estado.

A aplicação de tal Princípio é vista como forma de interpretação restritiva, baseado na concepção material do tipo penal, ${ }^{44}$ isto é, esse Princípio pode ser utilizado como um modo de descriminalizar condutas que são irrelevantes aos bens jurídicos protegidos pelo Direito Penal. O que se pretende com a aplicação de raciocínios dessa sorte é a redução da atuação do Direito Penal.

\footnotetext{
39 VICO MAÑAS, Carlos. Tipicidade e princípio da insignificância. cit., p.124 e ss.

40 PASCHOAL, Janaina Conceição. Direito penal... cit., p.44.

${ }^{41}$ FOUCAULT, Michel. Vigiar e punir... cit., p. 82-83.

42 GOMES, Mariângela Gama de Magalhães. O princípio da proporcionalidade no direito penal. 1. ed. São Paulo: Editora Revista dos Tribunais, 2003. p. 35 e ss.

43 PASCHOAL, Janaina Conceição. Constituição, criminalização e direito penal mínimo. 1. ed. São Paulo: Editora Revista dos Tribunais, 2003. p. 48.

44 VICO MAÑAS, Carlos. Tipicidade e princípio da insignificância... cit., p. 88 e ss.
} 


\subsection{Por que a hesitação em se aplicar o Princípio da Insignificância?}

É fato conhecido que o Princípio da Insignificância não é expresso no ordenamento jurídico; ${ }^{45}$ uma vez que o ordenamento criminaliza as condutas menores, muitos acreditam que o Princípio da Insignificância poderia ser tido como contrário a legalidade. ${ }^{46}$

Entretanto tal assertiva não merece crédito, pois, o que se contempla na esfera da insignificância pode ser considerado tão irrisório que não se insere nos tipos previstos, tanto é dessa forma que o número de delitos de bagatela que não são notificados às autoridades é imensurável, isto é, as cifras negras são altíssimas em se tratando de delitos bagatelares.

Jurisprudência e doutrina, pela dogmática, nos últimos tempos, empenhamse em estabelecer um "caráter regulador" ao Princípio da Insignificância. É importante verificar que a Constituição Federal de 1988 não atua de modo a criminalizar pequenas condutas; somente estabelece o regulamento a pequenas ofensas. ${ }^{47}$

Outros, ainda expressam dificuldade em entender quais condutas seriam consideradas bagatelares e a quais tal classificação seria negada. ${ }^{48}$ Indubitavelmente essa incerteza poderia gerar insegurança jurídica. Entretanto, sob a visão de um Direito Penal subsidiário, fragmentário, e, levando-se em conta o grau de lesividade ou ofensividade ao bem jurídico protegido pelo Direito Penal, a jurisprudência e a doutrina têm obtido êxito em delimitar condutas que recaem na esfera da insignificância. Para esse tipo de estudo, muitos concordam que é imprescindível a análise do bem jurídico situado no caso concreto. $^{49}$

O pensamento da ministra Ellen Gracie é condizente com esse modo de verificação, ou seja, priorizar-se uma análise do bem jurídico envolvido no caso concreto:

O princípio da insignificância está intimamente relacionado ao bem jurídico penalmente tutelado no contexto da concepção material do delito. Se não houver proporção entre o fato delituoso e a mínima lesão ao bem jurídico, a conduta deve ser considerada atípica, por se tratar de dano mínimo, pequeníssimo. O critério, em relação aos crimes contra o patrimônio, não pode ser apenas o valor subtraído (ou

\footnotetext{
VICO MAÑAS, Carlos. Tipicidade e princípio da insignificância... cit., p. 110.

SILVEIRA, Renato de Mello Jorge. Linhas reitoras da adequação social em direito penal... cit., p. 205.

VICO MAÑAS, Carlos. Tipicidade e principio da insignificância... cit., p. 110 e ss.

48 Id. Ibid., p. 99.

49 SILVEIRA, Renato de Mello Jorge. Linhas reitoras da adequação social em direito penal. 2009. Tese (Titularidade) - Faculdade de Direito, Universidade de São Paulo, São Paulo. p.206.
} 
pretendido à subtração) como parâmetro para a aplicação do princípio da insignificância. Consoante a critério da tipicidade material (e não apenas formal), excluem-se os fatos e comportamentos reconhecidos como de bagatela, nos quais tem perfeita aplicação o princípio da insignificância. $\mathrm{O}$ critério da tipicidade material deverá levar em consideração a importância do bem jurídico possivelmente atingido no caso concreto. (Habeas Corpus n. 92.531). ${ }^{50}$

Também, deve-se analisar a necessidade da imposição da pena, ou seja, o quanto que essa pena seria de proveito para a sociedade. Muitas vezes, a vítima de um delito bagatelar nem sequer está desejosa de que o infrator sofra alguma sanção penal; antes, deseja tão-somente que haja uma reparação daquilo de que foi privado. ${ }^{51}$

Ainda, é necessário avaliar o mal que essa pena causaria para a sociedade como um todo, ou seja, alguns, como Luiz Regis Prado, afirmam que se geraria insegurança jurídica o fato de se descriminalizar condutas previstas no ordenamento, ${ }^{52}$ entretanto, não se deve deixar de lembrar que uma pena privativa de liberdade, nesses casos, traria um malefício maior, pois o indivíduo que inserido no sistema carcerário brasileiro ${ }^{53}$ dificilmente iria conseguir se reinserir e se adaptar à vida social fora do cárcere. A família de tal indivíduo seria prejudicada com a ausência dele, e pior seria para a sociedade como um todo se ele desempenhasse a função de provedor dessa família.

Portanto, haveria maior insegurança para a sociedade o ato de se considerar como crimes os delitos bagatelares do que se houvesse a adoção da descriminalização de tais condutas.

PARTE II: Os Miseráveis

"Para o pobre, os lugares são mais longe".

(João Guimarães Rosa, "Primeiras Estórias")

SUANNES, Adauto. Bagatelas... cit., p. 15.

51 Ada Pellegrini Grinover, na obra "Novas Tendências do Direito Processual" discorre justamente sobre essa possibilidade.

52 SILVEIRA, Renato de Mello Jorge. Linhas reitoras da adequação social em direito penal. cit., p.215.

53 Id. Ibid., p. 209. 
1. O Pobre: o Inimigo social

\section{1. "A guerra os contra pobres" 54}

Interessante notar o vínculo que o direito criminal manteve com o grupo dominante. Isso pode ser verificado historicamente: por volta do século XV, o processo criminal, na maior parte dos países europeus, permanecia secreto, somente os acusadores poderiam conhecer o desenrolar dos fatos, os acusados nem sequer conheciam as acusações; isso mostra que o poder soberano deixa claro que o direito de punir jamais poderia advir do povo. ${ }^{55}$

O poder punitivo faz-se essencial para que essa forma de dominação seja firmemente estabelecida, ou seja, a determinação de qual seria a conduta delituosa ou qual seria o comportamento isento de punição, ou, mesmo, a quem tal punição deve ser direcionada, está relacionada à manifestação de poder. ${ }^{56}$ Essa manifestação, segundo relatos históricos, direciona-se à punição ao pobre. Por exemplo, por volta do século XVIII, havia previsão de pena de morte àqueles que cometessem delitos pouco graves tais como furtos domésticos, como apoderar-se de um pedaço de tecido. Tal punição recaia sobretudo nas camadas pobres, os criados eram os suspeitos e acusados, ainda que pouco se provasse contra eles e mesmo que eles viessem a restituir os objetos desaparecidos. ${ }^{57}$

Entretanto, tais circunstâncias, pelo fato de o povo se sentir inseguro e ameaçado em relação a essa forma de punição que se assemelhava a uma vingança sórdida, desencadearam manifestações e levantes populares: de um lado havia a "justiça" representada pelo soberano, do outro, o povo encolerizado. Além disso, ao que se refere a esse assunto, houve a simpatia de filósofos e magistrados para que se fizessem reconsiderações quanto às formas de punição. Através dessas agitações estabeleceu-se um espírito inquietante na esfera penal. ${ }^{58}$ Tanto foi assim que, até mesmo nos folhetins, atos criminosos passaram a ser elogiados, a exposição de uma criminalidade aceitável era uma forma de se mostrar a "monstruosidade dos fortes e poderosos". 59

A partir desses fatos, verifica-se a aceitação de formas de punição "mais humanizadas", na segunda metade do século XVIII. Muda-se a forma de se admitir a

\footnotetext{
54 Intertextualidade com a obra "A guerra contra os pobres", ou segundo algumas traduções "A guerra contra os fracos" de Edwin Black. Essa obra está baseada na análise de dados estatísticos que mostram a ânsia do governo norte-americano em cultivar uma nação livre de algumas minorias discriminadas como pobres, índios e negros.

55 FOUCAULT, Michel. Vigiar e punir. cit., p. 32.

56 Id. Ibid., p. 48.

57 Id. Ibid., p. 51-52.

58 Id. Ibid., p. 52-53.

59 Id. Ibid., p. 56.
} 
punição, ou seja, ela se mostra de modo mais ameno. Com o afrouxamento das punições, o pobre, faminto e desolado, deixa de ser o principal a cometer delitos. Outros criminosos, que tem suas formas de delitos mais elaboradas, passam a atuar de modo mais freqüente nas esferas da criminalidade, passa-se de uma "criminalidade de sangue" para uma "criminalidade de fraude". ${ }^{60}$

Curiosamente, contudo, as punições continuam a ser direcionadas aos mais pobres, ou seja, verifica-se que o sistema punitivo seleciona certas pessoas, mas deixa de selecionar outras em função de inúmeros fatores como a proteção por parte de detentores de poder: "para os amigos rege a impunidade e para os inimigos o castigo"; os inimigos merecem penas desproporcionais ou indeterminadas. ${ }^{61}$ Até mesmo aquilo que se estabeleceu como conduta delituosa passa a refletir essa preferência em detrimento dos mais pobres, ou seja, as condutas menos graves, como pequenos furtos, continuaram a ser punidas com rigorosidade. A pena é, portanto, provida de caráter simbólico, tem por objetivo o controle das massas por meio do exemplo da punição de alguns, geralmente da punição dos vulneráveis. ${ }^{62}$

A despeito de se ter universalizado as formas de castigar através do estabelecimento de um contrato social, no qual há o Estado punitivo de um lado, retendo para si o poder disciplinar e o direito de punir e tendo o intuito de garantir a paz social, e do outro lado o indivíduo inserido nessa sociedade, tendo assegurados seus direitos e deveres, ${ }^{63}$ observa-se uma luta desigual na medida em que para alguns não é fornecido meios lícitos de que possam se valer para garantir sua sobrevivência, ou seja, para esses resta unicamente se posicionarem como marginalizados, inimigos sociais, traidores, "monstros", anormais, ${ }^{64}$ miseráveis.

Essa rotulação de "inimigo", pois, verifica-se inserida ao longo da história do próprio poder punitivo por parte daqueles que exercem o poder, o intuito é justamente se posicionarem no controle desses denominados inimigos. ${ }^{65}$ Como acertadamente estabelece Zaffaroni, por inimigos não se deve entender apenas "criminosos graves", mas também "criminosos indesejáveis" como "pequenos ladrões". ${ }^{66}$

1.2. Seriam as mazelas sociais uma mera desculpa para o afronto a regras estabelecidas?

\footnotetext{
60 FOUCAULT, Michel. Vigiar e punir. cit., p. 64-66.

61 ZAFFARONI, Eugenio Raúl. O inimigo no direito penal. Tradução de Sérgio Lamarão. 2. ed. Rio de Janeiro: Editora Revan, 2007. p. 82-97.

62 Id. Ibid., p. 88-90.

63 FOUCAULT, Michel. Vigiar e punir. cit., p. 76.

${ }^{64}$ ZAFFARONI, Eugenio Raúl. O inimigo no direito penal. cit., p. 91-93.

65 Id. Ibid., p. 82.

66 Id. Ibid., p. 94.
} 
Infelizmente, muitos possuem uma posição preconceituosa em relação ao comportamento delituoso, ainda que esse comportamento esteja ligado a condutas irrelevantes ao Direito Penal, como o cometimento de pequenos furtos. Esse raciocínio provido de idéias pré-concebidas pode ser visualizado uma vez que se desenvolveram ao redor do mundo políticas que pregam "tolerância zero" e "movimentos de lei e ordem".

Também, essa áurea preconceituosa é claramente vislumbrada em relação ao tratamento hostilizado que enfrentam aqueles que o sistema penal selecionou e inseriu no cárcere. Tais pessoas tornam-se estigmatizadas, rotuladas e dificilmente serão reinseridos na sociedade adequadamente após terem sobrevivido às precárias condições carcerárias.

Sem dúvidas o sistema penal e suas formas de punição carecem de uma evolução de acordo com um pensamento mais aberto. Antigamente, conforme exposto por Michel Foucault na obra "Vigiar e Punir", os suplícios, ou seja, penas corporais com a finalidade de se alcançar insustentável sofrimento, ${ }^{67}$ eram utilizados como forma de penalizar condutas delituosas, ou, de acordo com o pensamento da época, expiar pecados. Por esse raciocínio, a extinção dos suplícios e o advento do cárcere foi uma forma impessoal de desvincular o Direito Penal de visões impregnadas de religiosidade.

Ainda, nos dias de Beccaria, com o advento das idéias iluministas, o cárcere pode ser considerado um avanço, pois foi uma tentativa de se estabelecer uma forma de pena igualitária, ou seja, as prisões reteriam bens preciosos (por exemplo, a liberdade) tanto de ricos quanto de pobres; tanto de nobres como de plebeus.

Atualmente, estudam-se formas de melhorias ao que se refere à punição de delitos. O modelo prisional atual mostra-se ultrapassado e todos admitem que ninguém que é inserido nos intricados sistemas prisionais, sai desses lugares recuperado; ao contrário, de acordo com as palavras de Zaffaroni, tentar reabilitar uma pessoa, no sistema penitenciário tal como ele é atualmente, seria o mesmo que tentar ensinar um indivíduo a jogar futebol dentro de um elevador. A experiência mostra que uma pessoa selecionada não se torna reeducada pelo sistema carcerário, ao contrário, os presídios desempenham o papel de tornar o indivíduo brutalizado e sem horizontes.

Seria, portanto, desarrazoado inserir no cárcere um indivíduo que cometeu um delito de menor ofensividade, que não lesionou nenhum bem jurídico digno de ser protegido pelo ramo penal do direito. Alguns argumentam que se não houvesse punição para tais casos, haveria insegurança jurídica para a sociedade, ou seja, de acordo com essa posição, haveria a prioridade da "segurança jurídica" em detrimento da própria justiça. ${ }^{68}$ Se esse indivíduo, pelo fato de ter cometido uma infração sem importância fosse inserido no sistema carcerário, correria o risco de ao contrário de ser redimido e "ressocializado"

${ }_{67}$ FOUCAULT, Michel. Vigiar e punir. cit., p. 31.

68 SILVEIRA, Renato de Mello Jorge. Linhas reitoras da adequação social em direito penal. cit., p. 216. 
como prega o discurso, ser pervertido, ${ }^{69} \mathrm{o}$ que se verificaria em oposição às próprias idéias decorrentes de um Estado que preza valores sociais e resguarda a dignidade da pessoa humana, ou seja, cuja a própria Constituição defende idéias de isonomia, a individualização e humanização da pena. Haveria, de fato, mais injustiça ainda, na medida em que a família desse indivíduo fosse privada de sua convivência.

O Direito Penal igualitário de Beccaria de certo modo fracassou. ${ }^{70}$ Os presídios são constituídos em sua maioria por pobres. É evidente que o sistema seleciona, para cair em suas malhas, os vulneráveis, isto é, os mais pobres. Isso se deve a fatores como: os mais pobres não possuem recursos econômicos para serem defendidos devidamente nos processos que lhes são movidos, tal circunstância fere evidentemente a ampla defesa, a presunção de inocência e a isonomia, princípios previstos na Constituição Federal de $1988 ;^{71}$ os crimes cometidos por pobres são classificados como providos de ameaça, enquanto os crimes cometidos por ricos, como a corrupção, ou os crimes econômicos, são encarados com mais benevolência por parte da sociedade, isto é, pelo fato de não haver uma interação física,não são vistos como tão lesivos.

Muitas vezes, o próprio mercado econômico, na ânsia de lucro, facilita que crimes como os de bagatela sejam cometidos. Por exemplo, para que haja maior consumo, uma infinidade de produtos se encontra dispostos nas prateiras de supermercados e de lojas. Essa disposição facilita que pessoas as quais não possuem recursos financeiros para esse consumo desenfreado furtem. ${ }^{72}$ Essa ânsia de consumismo pode ser explicada, também, pelo fato de haver uma imposição de idéias na mentalidade das pessoas por meio de propagandas espalhadas em cada esquina, as quais vendem que a felicidade pode ser materializada através de produtos oferecidos no mercado. Claramente, esse entendimento ilusório por parte das pessoas facilita o cometimento de delitos dessa monta. Seria, então, não só injusto como também injustificado que pessoas que caíram nessa verdadeira armadilha paguem com sua liberdade aquilo que os milhares de consumidores já pagaram, pois os preços dos produtos previamente são ajustados levando-se em conta as perdas que possam sobrevir.

2. O Confronto entre pobres e ricos no âmbito penal

BATISTA, Nilo. Punidos e mal pagos. 1. ed. Rio de Janeiro: Editora Revan, 1990. p. 123.

Id. Ibid., p. 123.

SUANNES, Adauto. Bagatelas. cit., p. 15.

72 Interessante notar a reflexão de SÁ, Alvino Augusto de. Criminologia clínica e psicologia criminal. 1. ed. São Paulo: Editora Revista dos Tribunais, 2007. p. 58-59: “A conduta socialmente desviada (...) [supõe] uma inabilidade na solução dos conflitos oriundos do convívio com a sociedade, com a cultura, com a civilização, num contexto em que se reeditam as relações de domínio, de poder, de exclusividade de certos direitos". 
Não é de se admirar que em um país como o Brasil, em que $70 \%$ da população é remunerada em até três salários mínimos, ${ }^{73}$ os presídios sejam compostos sobretudo por pobres. Entretanto, para muitos esse não seria o principal motivo para se verificar que os mais pobres são os mais vulneráveis à seleção do sistema penal. Para Zaffaroni, o caráter seletivo do sistema penal adquire forma de ameaça direcionada aos fragmentos mais humildes da sociedade. ${ }^{74}$

É comum que se diga que o Brasil é o país da impunidade, entretanto, essa é uma frase generalizada e indevida visto que o cárcere está abarrotado de indivíduos, principalmente de pobres. A impunidade, na visão de muitos, dentre esses Nilo Batista, direciona-se às classes dominantes. ${ }^{75}$

Alguns frisam que o fato de se verificar uma maior punibilidade aos pobres se deve a dificuldade ao acesso à justiça que os mais pobres se deparam, ou seja, os menos favorecidos financeiramente são incapazes de arcar com as despesas de uma defesa de qualidade. ${ }^{76}$ Outros atentam para o fato de os mais pobres cometerem delitos em que há maior interação física com a comunidade, ou seja, maior "confronto" perante a sociedade, maior "ameaça" no sentido físico; por exemplo, a um indivíduo que não possui moradia, ou vínculo empregatício, infelizmente, conforme mostra a prática judiciária, se acaso fosse aprisionado lhe seriam negados os pedidos de liberdade provisória.

É interessante estabelecer que apesar de há muito se ter notado que o crime não é "disfunção" própria das camadas menos favorecidas, ${ }^{77}$ aos crimes usualmente cometidos por ricos, como o crime de corrupção nas esferas políticas, por exemplo, não se verifica uma forma de tratamento acirradamente reprovadora por parte da sociedade.

Mesmo que essa forma de delito, não raro denominada crimes de colarinhobranco, ou seja, crimes cometidos por indivíduos provenientes de altos estratos sociais, possa se apresentar mais lesiva a bens jurídicos caros à sociedade (por exemplo, os crimes de desvio de recursos públicos) do que se apresentam os delitos de pequena monta, como os bagatelares, curiosamente se observa uma menor reprovação jurídica e social a eles. Pelo fato de as pessoas não se indignarem com essa criminalidade de colarinho-branco, o próprio sistema judiciário se faz brando por admitir certas imunidades a esses criminosos, como o estabelecimento de penas mais leves, prisões diferenciadas, tribunais especiais, etc. ${ }^{78}$

\footnotetext{
Fonte: IBGE (Instituto Brasileiro de Geografia e Estatística), disponível em: <http: www.ibge.gov.br>.

ZAFFARONI, Eugenio Raúl; PIERANGELI, José Henrique. Manual... cit., p. 96.

BATISTA, Nilo. op. cit., p. 38.

Id. Ibid., p. 35 e ss.

SHECAIRA, Sérgio Salomão. Criminologia. 2. ed. São Paulo: Editora Revista dos Tribunais, 2008. p. 195.

78 SHECAIRA, Sérgio Salomão. Criminologia. 2. ed. São Paulo: Editora Revista dos Tribunais, 2008. p. 200201.
} 
Muitas vezes tais crimes nem sequer chegam ao conhecimento do público, pois, não raro, são encobertos pelas próprias autoridades do governo. ${ }^{79}$

Em relação ao confronto da criminalidade do colarinho-branco cometida por ricos e da criminalidade bagatelar cometida por pobres pode-se depreender o caráter elitista que o Direito Penal brasileiro apresenta, ou seja, mais uma vez observa-se o controle que as camadas superiores detêm em relação ao Direito Penal.

Muitos consideram que essa forma de criminalidade cometida por ricos mostra-se ainda mais sórdida do que as demais, pois ela não pode ser justificada pelas condições adversas sofridas pelos mais pobres. ${ }^{80}$ Isso unicamente comprova que o sistema penal é fruto da estrutura econômica vigente, uma vez que para alguns, os ricos, mostrase brando, mesmo diante de grande afronta a bens jurídicos; diante de outros, os pobres, mostra-se rigoroso, ainda que em face de lesões mínimas, como diante de pequenos furtos.

O exposto reafirma, pois, o pensamento de Nilo Batista o qual frisa que para o brasileiro pobre há, pois, duas alternativas: trabalhar e auferir ganhos irrisórios os quais, na maioria das vezes, não são suficientes para suprir necessidades essenciais, ou se enveredar pelos meandros da "vadiagem" e ser encarcerado por isso. ${ }^{81}$

3. Afinal, por que os pobres são os vigiados e punidos?

O Direito Penal, através dos séculos, desempenhou o papel de assegurar que houvesse mão-de-obra para alimentar o sistema político-econômico, servindo, assim para impedir que os trabalhos deixassem de ser realizados. ${ }^{82} \mathrm{O}$ Direito Penal, pois, atendeu ao fim interposto por um grupo dominante que se interessava em maximizar os lucros através da exploração do trabalho dos mais pobres, bem como serviu para garantir a posição de uma classe dominante.

É notória a ligação entre o modo de produção vigente e os modos de punição em vigor: uma economia escravista poderia ter como forma de punição a escravidão, uma sociedade industrial ou manufatureira poderia ter como pena o trabalho forçado, uma economia monetária poderia ter como punição multas, etc. ${ }^{83}$

Muitos são os exemplos dessa finalidade do Direito Penal: desde a inserção de um tipo penal denominado vadiagem no sistema inglês em meados da revolução industrial

\footnotetext{
Id. Ibid., p. 201.

80 Id. Ibid., p. 200.

81 BATISTA, Nilo. Punidos e mal pagos. 1. ed. Rio de Janeiro: Editora Revan, 1990. p. 35 e ss.

82 Id. Ibid.

83 RUSCHE, Georg; KIRCHHEIMER, Otto. Punição e estrutura social. Tradução de Gizlene Neder. 2. ed. Rio de Janeiro: Editora Revan, 2004. p. 20.
} 
até a criação do delito de greve, cuja punibilidade recaia àqueles que se recusavam a aceitar o trabalho tal como ele era disposto, conforme estabelecido no Código Penal francês do século XIX. ${ }^{84}$

No Brasil não foi diferente. Um exemplo provém da época do militarismo: havia o fornecimento de mão-de-obra com baixo custo para as multinacionais, enquanto se punia a "vadiagem" e a greve. ${ }^{85}$

Disso decorre que a punição penal aos pobres pode ser entendida como forma de garantir que haja equilíbrio econômico ao que se refere ao mercado regente. O que ocorre pode ser entendido como um armazenamento de pessoas que devem ser administradas de acordo com a lógica do poder.

Até mesmo o fato de se classificar as ilegalidades e inseri-las em um código tem forte influência política, ou seja, trata-se de uma das formas de manifestação do poder punitivo exercido por um grupo dominante. Através desse poder, alguns indivíduos, e isso com a finalidade de se evidenciar essa forma de se impor terror, são desprovidos da característica de serem tidos como cidadãos e passam a ser designados como inimigos, marginais, loucos e anormais. ${ }^{86}$

Há quem diga que é melhor para o sistema econômico que se crie uma massa de neutralizados do que estabelecer condições adequadas de produção em que essas pessoas possam ser inseridas. ${ }^{87}$

Apesar de se observar, em relação à punição dos mais pobres, uma forte influência dos poderes econômicos e políticos, a mais notável forma de influência é verificada através do poder ideológico. Essa forma sutil de poder é capaz de submeter os corpos por intermédio de idéias; mostra-se uma forma de controle mais eficaz, pertinente e duradoura. Através das amarras das idéias, o Direito Penal, sua forma de controle e os grupos dominadores mostram-se solidamente estabelecidos.

A determinação das penas, bem como o estabelecimento da imposição das ações que serão consideradas delituosas, segundo essa visão ideológica de dominação, devem ser, portanto, próximas e inseridas a uma "tecnologia de representação", isto é, a punição deve ser uma arte, deve se mostrar arraigada no indivíduo de modo que ele não perceba essa influência. Ele deve encarar esses valores impostos como sendo naturais, não deve possuir consciência da natureza artificial dessas imposições; mais do que isso, o ideal

\footnotetext{
Id. Ibid., p. 35 e ss.

Id. Ibid., p. 36.

86 FOUCAULT, Michel. Vigiar e punir. cit., p. 85.

87 SHECAIRA, Sérgio Salomão. Tolerância zero. Revista Brasileira de Ciências Criminais, São Paulo, n. 77, mar./abr. 2009. p. 261 e ss.
} 
seria que essas imposições fossem capazes de despertar os terrores interiores como modo eficaz e perfeito de prevenção de condutas criminosas. ${ }^{88}$

O que se pretende, com isso, é tornar o crime pouco atraente, isto é, a forma de punição deve se apresentar atemorizante de modo a demover o desejo do benefício que o ato criminoso possa trazer. O primordial nesse âmbito de dominação pelo poder ideológico, não é se utilizar do poder brutal representado pela força, segundo essa forma de raciocínio um poder embasado nas paixões e sensibilidades deve ser utilizado. Por exemplo, no caso de uma pena aplicada a um indivíduo que comete roubo, segunda a lógica do poder ideológico, deve haver punição do modo semelhante ao ato delituoso praticado: tal indivíduo deve perder seus bens a fim de aprender a respeitar os de outros. Desse modo pode-se dizer que há uma ligação entre os interesses econômicos e os modos ideológicos de se estabelecer punição. ${ }^{89}$

Ainda, sob essa visão de dominação ideológica, o castigo é estabelecido não somente com o intuito de retribuir o mal ao culpado; é interposto a fim de que, principalmente, todos observem e alguns se sintam derrogados de seus intuitos de cometer ações semelhantes. ${ }^{90}$

Com o advento do sistema privativo da liberdade foram distribuídas idéias que cultuavam o trabalho e qualificavam-no como o meio mais indicado de se restabelecer o indivíduo para a reinserção social. Por isso, evitava-se o estabelecimento de penas muito breves, para não se interromper a aprendizagem do ofício, ou de penas perpétuas, para que os condenados não se sentissem desanimados e desistissem dessa forma de "correção" não se comportando "adequadamente", ou seja, para que eles não se rebelassem contra o órgão punitivo.

Interessante notar a relação entre a duração da pena e o aproveitamento econômico proveniente do trabalho dos condenados. Portanto, ao que se refere ao cárcere é correto afirmar, que, além de se mostrar como forma amedrontadora de punição, também pode ser visto como um instrumento de conversão a valores impostos e escolhidos através do poder exercido pelas camadas superiores. ${ }^{91}$

O poder disciplinar se faz necessário para situações tais como a de dominação ideológica. Por meio de tal poder preserva-se a política que prega o "bom adestramento" a qual aumenta a eficiência da "correta disciplina". O intuito é adestrar as multidões confusas manipulando seus modos de entendimento. Essa estratégia é comparada a uma “fábrica de indivíduos”, pois através dela o poder disciplinar é capaz de utilizá-los como

\footnotetext{
FOUCAULT, Michel. Vigiar e punir cit., p. 87.

Id. Ibid., p. 88-89.

90 Id. Ibid., p. 90-91.

91 Id. Ibid., p. 100-103.
} 
meio para o exercício de poder. Seu sucesso está relacionado à dominação hierárquica por meio da vigilância juntamente com o controle dos modos de punição. ${ }^{92}$

Por meio do poder disciplinar estabelece-se vigilância àqueles que são, em suma, objetos da dominação. "Vigilâncias hierárquicas" mostram-se comuns em instituições como manicômios, prisões, asilos, etc. Nas palavras de Foucault, esse processo é denominado "encastramento", e está presente desde a arquitetura das já citadas "instituições de seqüestro" até o regulamento das condutas nesses recintos, como por exemplo, a imposição de valores aos inseridos nos sistemas prisionais. Por meio dessa vigilância há a imposição controlada e calculada de um processo que tende a transformar o indivíduo inserido nesse meio; ele deve se tornar "doce e conhecível". ${ }^{93}$

Essas instituições disciplinares produziram, pois, uma inovação ao que se refere ao controle. A persistente vigilância aos comportamentos se tornou uma eficiente forma de imposição de valores por meio do "olhar disciplinador". Essa idéia de vigilância redeu resultados tão surpreendentes que se contrataram pessoas especializadas que tinham por função unicamente vigiar, ou fiscalizar as ações de outros, por exemplo, os operários nas fábricas eram duramente fiscalizados por seus chefes. As formas de vigilância, então, tornam-se indispensáveis para o estabelecimento de bons resultados econômicos através da exploração dos vigiados. ${ }^{94}$

Por meio da vigilância o poder disciplinar também se manifesta ao que se refere a castigos e punições, isto é, lei, regulamento, regras devem ser seguidas, caso isso não ocorra, estabelece-se a punição ao infrator. Tais castigos são aplicados a fim de que os desvios se reduzam. A punição disciplinar é aplicada, também, com a finalidade de se "corrigir" o que se determinou que fosse o correto. ${ }^{95}$ Essas relações de dominação por meio do poder ideológico são, portanto, estabelecidas pela imposição de saberes préestabelecidos aos inseridos nas "instituições de seqüestro".

O poder disciplinar, por meio desses mecanismos de controle ideológico, aos poucos molda a individualização do ser inserido nessa esfera institucional; das disciplinas decorriam um papel ligado a proteção, entretanto, essa função evoluiu para um papel impositivo com o fim de aumentar a utilidade dos indivíduos inseridos nessas instituições.

O poder disciplinar, por meio da vigilância ou fiscalização e da imposição de saberes e valores calculadamente estabelecidos, molda os indivíduos determinando comportamentos e condutas.

\footnotetext{
FOUCAULT, Michel. Vigiar e punir... cit., p.143.

Id. Ibid., p. 143-145.

Id. Ibid., p.145-147.

95 Id. Ibid., p. 148-154.
} 

punições. ${ }^{96}$

Caso haja desrespeito às regras impostas, o poder disciplinar faz valer as

PARTE III: Um Admirável Mundo Novo

"É preciso sobretudo acabar com a dominação..."

(Michel Foucault, "Microfísica do Poder")

1. Uma crítica ao sistema penal brasileiro

Para, muitos o sistema penal tem por função a proteção da sociedade; entretanto, tendo em vista os modos de que se vale o Direito Penal, ou seja, a retribuição do mal ligada a um caráter intimidador e preventivo, torna-se difícil a concepção do caráter benéfico da idéia de proteção. A verdade é que o Direito Penal se mostra como um meio violento com o intuito que determinadas normas impostas sejam seguidas.

Tais normas estão em conformidade com os valores impostos por determinado grupo social dominante, o que torna o sistema penal um instrumento controlado por esse grupo, ou seja, observa-se a defesa daquilo que tal grupo considera digno de ser resguardado..$^{97}$

A punição, portanto, é determinada por forças sociais, principalmente pelas forças econômicas. ${ }^{98}$ Ainda, como as punições são direcionadas aos estratos sociais desprivilegiados, elas tendem a serem tais que forçam com que os vulneráveis tenham temor.

Se antes, ao longo de toda história das lutas de classes, o Direito Penal teve a função principal de preservar as forças de trabalho, hoje há quem afirme que a função essencial do direito criminal é a de controlar as camadas desprivilegiadas, armazenando-as, tornando inúteis os considerados indesejáveis e, com isso, preservar a hierarquia social. ${ }^{99}$

Tais políticas de neutralização e armazenamento são facilmente verificáveis ao que se diz respeito a uma intervenção máxima do Direito Penal. Na verdade, devido a idéias pré-concebidas, novamente os "vulneráveis" são os prejudicados, por exemplo, na Europa os imigrantes são vistos como inimigos, sendo, pois, considerados os potenciais

\footnotetext{
96 FOUCAULT, Michel. Vigiar e punir... cit., p. 173 e ss.

97 RUSCHE, Georg; KIRCHHEIMER, Otto. Punição e estrutura social. 2. ed. Rio de Janeiro: Editora Revan, 2004. p. 8.

98 Id. Ibid., p. 20

99 Id. Ibid., p. 24
} 
criminosos. Observa-se uma atribuição de reprovabilidade a minorias, como em relação aos mexicanos, nos Estados Unidos da América. ${ }^{100}$

É fato conhecido que o acirramento do poder punitivo ao invés de prevenir que atos delituosos ocorram, só tem por conseqüência encerrar um enorme contingente de indivíduos nas prisões. Se tal intuito punitivo se mostrasse verdadeiro, ou seja, se previsão de pena e índice de criminalidade se mostrassem inversamente proporcionais, certamente países que adotam penas excêntricas e deturpadoras, como a pena de morte, estariam isentos de criminalidade, fato esse distante da realidade.

A prática ensina que para redução da criminalidade certas políticas precisariam ser adotadas, por exemplo, a melhoria de escolas, o investimento em meios salutares de entretenimento, uma nova estruturação do espaço urbano, segundo o viés reformista pregado na Escola de Chicago.

Essa linha de raciocínio delibera uma redução do controle social formal, ou seja, o controle utilizado por instituições que exercem o poder disciplinar estatal, como o poder de polícia, por exemplo, e um aumento do controle social informal, ou seja, um controle por parte de esferas informais, por exemplo, o controle comunitário em uma cidade pouco populosa, ${ }^{101}$ com a participação ativa da comunidade.

No Brasil, sociólogos e juristas deliberam sobre medidas semelhantes. Propõem-se medidas como a substituição das penas privativas de liberdade por um trabalho útil à comunidade; discutem-se formas de se implantar melhorias nas "instituições de seqüestro", como acertadamente designou Foucault ao se referir a instituições punitivas.

Atualmente o acesso à justiça é um assunto constantemente debatido; sobre isso, muitos argumentam que a criação dos Juizados Especiais pode ser considerada um avanço. As Defensorias Públicas constituem-se uma das formas mais eficientes, hoje no Brasil, de se estabelecer a justiça aos mais pobres. Estabeleceram-se, também, princípios e garantias na Constituição Federal de 1988 que tem por alvo a melhoria ao que se refere ao acesso à justiça.

A intervenção penal mínima na vida dos indivíduos pode ser tida como uma das formas de medidas para se alcançar esse avanço que se refere ao combate das injustiças sociais na esfera judicial. O Direito Penal mínimo poderia ser entendido como uma forma de se reduzir o controle formal do âmbito penal. O Princípio da Insignificância mostra-se essencial para esse fim, ou seja, através da aplicação dele em relação a delitos bagatelares, muitos seriam poupados do contato com os dissabores presentes nas instituições punitivas brasileiras.

\footnotetext{
100 SHECAIRA, Sérgio Salomão. Criminologia. cit., p. 335.

101 Id. Ibid., p. 172.
} 


\section{Conclusão}

Zaffaroni, Nilo Batista, Foucault, Baratta, enfim, muitos foram os pensadores que se preocuparam com uma questão tanto inquietante como, talvez, indecifrável: por que as estruturas de dominação estão fundadas na punibilidade ao pobre?

O estudo apresentado tem como tema a desigualdade social que se verifica em relação ao alcance por parte dos mais pobres à Justiça.

Discute-se, nesse trabalho, a reprovação social e jurídica em relação ao pobre que comete delitos irrelevantes penalmente - os delitos bagatelares - mas que não deixam de, muitas vezes, sofrer graves penalidades.

Defende-se a descriminalização das condutas delituosas bagatelares por meio de raciocínios judiciais e ideológicos como a intervenção penal mínima na vida das pessoas, ou seja, a idéia que o Direito Penal deve ser utilizado somente no último caso, como último recurso, pelo motivo que ao Direito Penal é delegado o poder de privar o homem de um bem caríssimo, o bem jurídico liberdade. Portanto, deve existir uma proporcionalidade entre a ação delituosa apta a mover as engrenagens do ramo penal do direito e o bem jurídico que será burlado, ou seja, no caso, a liberdade do indivíduo.

Argumenta-se que, embora os delitos bagatelares, ou seja, furtos irrelevantes para a sociedade, estejam tipificados formalmente no ordenamento jurídico brasileiro, tais condutas devem, materialmente, ser consideradas atípicas, pois uma análise do bem jurídico lesionado, no caso concreto, não deve ser deixada de se levar em consideração. Nesse estudo, dá-se ênfase que o bem jurídico mais relevante perante a sociedade deve ser priorizado em detrimento do menos relevante, segundo o princípio da ofensividade.

O Princípio da Insignificância, desenvolvido por Roxin, mostra-se essencial para descriminalizar essas condutas irrelevantes. Embora essa linha de raciocínio pareça evidente, há correntes contrárias a aplicação de tal princípio sob argumentos como a suposta afronta ao Princípio da Legalidade, pois é fato que o Princípio da Insignificância não está previsto no ordenamento jurídico. Entretanto, os delitos bagatelares são condutas irrisórias, e, por isso, materialmente, nem sequer alcançam a posição de tipo.

Ainda que o Princípio da Insignificância não esteja disposto no ordenamento jurídico, jurisprudência e doutrina, cada vez mais, estão estabelecendo um caráter regulador para ele. Tanto é assim que o Supremo Tribunal Federal aceita esse posicionamento, embora haja correntes contrárias.

Muitos são da opinião que o sistema penal deve usar de rigorosidade excessiva como meio de prevenção à criminalidade, pregam a intolerância mesmo diante do mais ínfimo dos delitos sob pena de se gerar insegurança jurídica. No entanto, essa linha de raciocínio tem por conseqüência não o combate à criminalidade, mas o aumento de pessoas nos presídios. 
Com efeito, verifica-se que nos presídios o número de indivíduos pobres supera em muito o de abastados financeiramente. Isso se deve a diversos fatores, como por exemplo: fatores históricos, ou seja, o pobre, ao longo dos séculos, foi tratado com preconceito e antipatia por parte de grupos que detinham o poder; fatores econômicos, ou seja, a força de trabalho do pobre moveu durante séculos as engrenagens da economia, de fato, havia, mesmo, punição àqueles que não se adaptavam aos trabalhos impostos pelas classes dominantes - crimes de vadiagem - além disso, as denominadas "instituições de seqüestro" eram lugares utilizados para "reeducar" mediante o trabalho aos "desregrados".

O poder de dominação evoluiu, assim, para uma forma mais sutil de controle às massas, ou seja, o poder exercido mediante a ideologia. Através dele as classes dominantes puderam arraigar firmemente seus valores e estabelecer o controle social segundo seus desígnios, por exemplo, por meio da imposição de normas e de ações consideradas aceitáveis ou não. Em relação aqueles que não se adaptaram a esse novo ambiente é necessário readaptá-los, reeducá-los, vigiá-los, posto que poderiam vir a ser um perigo para o sistema; é necessário puni-los.

Hoje muitos acreditam que os presídios tornaram-se lugares de depósitos dos desfavorecidos, dos miseráveis, pois, por essa lógica, tornou-se mais aproveitável para os grupos dominantes encerrar os "inúteis" no cárcere do que se criar condições para que esses inimigos sociais se reinserissem na sociedade.

Por isso, pensadores deliberam quais seriam as solução para esses problemas: melhoria das instituições punitivas, abrandamento da intervenção penal nas vidas das pessoas, redução da criminalidade, modos de se ter acesso à justiça por parte de todos, etc.

Pois é fato que se verifica ainda hoje que o Direito Penal mostra-se um instrumento nas mãos dos grupos dominantes, que por meio dele, manobram as massas, e estabelecem, assim, seus valores e seus vícios, bem como cravam nas linhas do tempo sua história de dominação e poder sobre os miseráveis.

São Paulo, setembro de 2009.

\section{Referências}

BARATTA, Alessandro. Criminologia crítica e crítica do direito penal: introdução à sociologia do direito penal. 3. ed. Tradução de Juarez Cirino dos Santos. Rio de Janeiro: Editora Revan, Instituto Carioca de Criminologia, 2002.

BATISTA, Nilo. Punidos e mal pagos. Rio de Janeiro: Editora Revan, 1990. 
BECCARIA, Cesare. Dos delitos e das penas. Tradução de Torrieri Guimarães. São Paulo: Editora Martin Claret, 2006.

CAMARGO, Antonio Luis Chaves. Motivo, vontade, intenção, dolo. 1986. Tese (Livre Docência) - Faculdade de Direito, Universidade de São Paulo, São Paulo.

CANOTILHO, José Joaquim Gomes. Estudos sobre direitos fundamentais. São Paulo: Revista dos Tribunais, 2008.

ENGELS, Friedrich. A situação da classe trabalhadora na Inglaterra. Tradução por B. A. Shumann. São Paulo: Boitempo Editorial, 2007.

FARIA, José Eduardo. Direito e conjuntura. São Paulo: Editora Saraiva, 2008.

FOUCAULT, Michel. Microfísica do poder. 26. ed. Tradução de Roberto Machado. Rio de Janeiro: Editora Graal, 1979.

FOUCAULT, Michel. Vigiar e punir. 35. ed. Tradução de Raquel Ramalhete. Petropólis: Editora Vozes, 2008.

GOMES, Mariângela Gama de Magalhães. O Princípio da proporcionalidade no direito penal. São Paulo: Editora Revista dos Tribunais, 2003.

GRINOVER, Ada Pellegrini. Novas tendências do direito processual penal. 2. ed. Rio de Janeiro: Editora Forense, 1990.

GROSNER, Marina Quezado. A seletividade do sistema penal na jurisprudência do Superior Tribunal de Justiça: O Trancamento da Criminalização Secundária por Decisões em "Habeas Corpus”. São Paulo: Instituto Brasileiro de Ciências Criminais, 2008.

IHERING, Rudolf Von. A Luta pelo direito. 23. ed. Tradução de João de Vasconcelos. Rio de Janeiro: Editora Forense, 2007.

JAKOBS, Günther. Derecho penal del enemigo. Tradução de Manuel Cancio Meliá. Madrid: Civitas, 2003.

. Fundamentos do Direito Penal. Tradução de André Luís Callegari. São Paulo: Revista dos Tribunais, 2003.

. Sociedade, norma e pessoa. 1. ed. Tradução de Maurício Antonio Ribeiro Lopes. São Paulo:

Ed. Manole, 2003.

LOPES, Maurício Antonio Ribeiro. Princípio da insignificância no direito penal. Análise à luz das Leis 9.099/95 (Juizados Especiais Criminais), 9.503/97 (Código de Trânsito Brasileiro) e da jurisprudência atual. 2. ed. São Paulo: Revista dos Tribunais, 2000. v. 2.

MARX, Karl; Engels, Friedrich. Manifesto do partido comunista (1848). Tradução de Sueli Tomazini Barros Cassal. Porto Alegre: Editora L\&PM, 2001. 
MORE, Thomas. A utopia. Tradução de Maria Isabel Gonçalvez Tomás. 2. ed. São Paulo: Ed. Martin Claret, 2000.

PAIVA, Luiz Guilherme Mendes de. A fábrica de penas: racionalidade legislativa e a lei dos crimes hediondos. Rio de Janeiro: Editora Revan, 2009.

PASCHOAL, Janaina Conceição. Constituição, criminalização e direito penal mínimo. São Paulo: Editora Revista dos Tribunais, 2003.

. Direito penal: parte geral. São Paulo: Editora Manole, 2003.

PRADO, Luiz Regis. Bem jurídico-penal e Constituição. 3. ed. São Paulo: Editora Revista dos Tribunais, 2003.

PRESTES, Cássio Vinicius D. C. V. Lazzari. O princípio da insignificância como causa excludente da tipicidade no direito penal. São Paulo: Memória Jurídica, 2003.

REALE, Miguel. Teoria tridimensional do direito. 3. ed. São Paulo: Editora Saraiva, 1980.

ROSA, João Guimarães. Primeiras estórias. São Paulo: Ed. Nova Fronteira, 1988.

ROUSSEAU, Jean-Jacques. O contrato social. Tradução de Paulo Neves. Porto Alegre: Ed. L\&PM, 2007.

ROXIN, Claus. Politica criminal y sistema de derecho penal. Tradução de Francisco Muños Conde. Barcelona: Bosch, 1972.

RUSCHE, Georg; KIRCHHEIMER, Otto. Punição e estrutura social. 2. ed. Tradução de Gizlene Neder. Rio de Janeiro: Editora Revan, 2004.

SÁ, Alvino Augusto de. Criminologia clínica e psicologia criminal. São Paulo: Editora Revista dos Tribunais, 2007.

SHECAIRA, Sérgio Salomão. Criminologia. 2. ed. São Paulo: Editora Revista dos Tribunais,2008. . Tolerância zero. Revista Brasileira de Ciências Criminais, São Paulo, n. 77, mar./abr. 2009.

SILVEIRA, Renato de Mello Jorge. Crimes sexuais: bases críticas para a reforma do direito penal sexual. São Paulo: Editora Quartier Latin, 2008.

. Direito penal econômico como direito penal de perigo. São Paulo: Editora Revista dos Tribunais, 2006.

. Linhas reitoras da adequação social em direito penal. 2009. Tese (Titular) - Faculdade de Direito, Universidade de São Paulo, São Paulo.

SUANNES, Adauto. Bagatelas. Boletim IBCCRIM, São Paulo, n. 200, jul. de 2009.

TAVARES, Juarez. Critérios de seleção de crimes e cominação de penas. Revista Brasileira de Ciências Criminais, São Paulo, n. esp., dez. 1992. 